\title{
Review \\ Horizontal Histopathology Correlation with In Vivo Reflectance Confocal Microscopy in Inflammatory Skin Diseases: A Review
}

\author{
Giuseppe Broggi ${ }^{1, *(\mathbb{D}}$, Anna Elisa Verzì ${ }^{2}$, Francesco Lacarrubba ${ }^{2}\left(\mathbb{D}\right.$, Giuseppe Micali ${ }^{2}$ and Rosario Caltabiano ${ }^{1}(\mathbb{D}$ \\ 1 Department of Medical, Surgical Sciences and Advanced Technologies "G.F. Ingrassia”, Anatomic Pathology, \\ University of Catania, 95123 Catania, Italy; rosario.caltabiano@unict.it \\ 2 Dermatology Clinic, University of Catania, 95123 Catania, Italy; annaeverzi@gmail.com (A.E.V.); \\ francesco.lacarrubba@unict.it (F.L.); giuseppe.micali@unict.it (G.M.) \\ * Correspondence: giuseppe.broggi@gmail.com; Tel.: +39-0953782021; Fax: +39-0953782023
}

Citation: Broggi, G.; Verzì, A.E.; Lacarrubba, F.; Micali, G.; Caltabiano, R. Horizontal Histopathology Correlation with In Vivo Reflectance Confocal Microscopy in Inflammatory Skin Diseases: A Review. Appl. Sci. 2022, 12, 1930. https://doi.org/10.3390/app12041930

Academic Editor: Jongsung Lee

Received: 15 December 2021

Accepted: 10 February 2022

Published: 12 February 2022

Publisher's Note: MDPI stays neutral with regard to jurisdictional claims in published maps and institutional affiliations.

Copyright: (C) 2022 by the authors. Licensee MDPI, Basel, Switzerland. This article is an open access article distributed under the terms and conditions of the Creative Commons Attribution (CC BY) license (https:// creativecommons.org/licenses/by/ $4.0 /$ )

\begin{abstract}
Horizontal histopathological sections (HHSs) have been reported to show a strong correlation with images obtained via in vivo reflectance confocal microscopy (RCM), as both reflect the same horizontal plane of the skin. Although vertical histopathology remains the diagnostic gold standard for most neoplastic and inflammatory skin diseases, HHSs represent a useful tool to validate the RCM features of some inflammatory disorders, including psoriasis, discoid lupus erythematosus, and eczema. The aim of the present review is to summarize the state of the art on the existing correlations between HHS and RCM in this field and to emphasize that RCM may represent a useful diagnostic tool to discriminate between diseases with similar clinical presentations.
\end{abstract}

Keywords: horizontal histopathology; horizontal histopathological sections; diagnosis; correlation; inflammatory skin diseases; reflectance confocal microscopy

\section{Introduction}

The introduction of new methods capable of allowing clinicians to render a noninvasive diagnosis as accurately as possible has always represented one of the most captivating frontiers of dermatology.

Reflectance confocal microscopy ( $\mathrm{RCM}$ ) is a non-invasive diagnostic technique that is used to study several skin diseases and enables a horizontal high-resolution view of the skin, from the stratum corneum to the papillary dermis with a maximum depth of $250 \mu \mathrm{m}$ [1]. As regards inflammatory skin diseases, it has been reported to be sensitive enough to differentiate between entities with similar clinical presentation as it allows the identification of the main features of psoriasiform, spongiotic, and interface dermatitis [2]. In order to obtain an optimal correlation with the horizontal plane of RCM, horizontal histopathological sections (HHSs) are needed and have recently been reported in various skin disorders [1]. The aim of the present review is to analyze the existing literature regarding the correlation between RCM and HHS findings in inflammatory skin diseases.

\section{Reflectance Confocal Microscopy and Horizontal Histopathology}

The introduction of RCM in clinical practice has definitely revolutionized the noninvasive diagnostic approach to skin diseases. While in the past the execution of skin biopsies followed by histopathological examination has represented the diagnostic "gold standard" for the majority of skin disorders, RCM, by providing a visualization of the skin with an almost "cellular" resolution, allows biopsies to be avoided on areas that are cosmetically sensitive, or at sites prone to slow healing, or in young-aged patients $[3,4]$. This technique actually represents an important adjunctive tool in the dermatologist's armamentarium, together with dermatoscopy, to evaluate both neoplastic and inflammatory skin lesions in a non-invasive manner, as it can be considered as the link between clinical examination, dermoscopy, and histopathology [3]; as evidence of this, although it is currently 
used mainly for experimental purposes, reimbursement codes have been provided for RCM in some countries, where its application in clinical practice is now a consolidated reality [3]. The well-known limitations of RCM include the depth of visualization/penetration not exceeding $250 \mu \mathrm{m}$ and the possibility to visualize the skin only on a horizontal plane.

The use of HHSs in the diagnostic practice of the dermatopathologist is currently limited to scalp biopsies for some forms of alopecia [5-7]. Numerous studies have been conducted to evaluate the superiority of HHSs over conventional vertical histopathology in this context, and controversial results have been obtained [5-7]. The current trend is to combine both vertical and horizontal histopathology, by performing a double biopsy whenever possible, or, in the event that only one biopsy is available, to prefer the horizontal sectioning of scalp biopsies to the vertical one [6,7]. In recent years, our research group has used HHSs for experimental purposes to reproduce the same skin observation plane of RCM and to validate its use in clinical practice [1].

\section{Psoriasis}

Psoriasis is a chronic relapsing and remitting disease of the skin with an incidence of $1-2 \%$ in Caucasians [8]. Men and women are equally affected. The first peak of incidence is in early adult life, while the second peak of incidence appears around the sixth decade. Plaque psoriasis is clinically characterized by raised, sharply demarcated lesions with a silvery scaly surface. The most common sites of involvement are the scalp, the knees, the elbows, and the lower back [9-11]. Less common forms of psoriasis are (1) guttate psoriasis, typical of younger patients; (2) psoriasis inversa, usually located in the flexures; (3) pustular psoriasis, with sterile pustules; (4) psoriatic erythroderma, affecting the entire skin surface; (5) palmoplantar pustular psoriasis, localized to the palmoplantar regions; and (6) acrodermatitis continua of Hallopeau, involving the nails and the surrounding skin. Even if the clinical diagnosis of psoriasis is often easy, non-invasive diagnostic tools such as dermoscopy and RCM may be useful in difficult cases, i.e., atypical localizations, scalp or genital lesions, and pediatric presentation [12,13].

The main RCM features of psoriasis have been reported to show overlaps with HHSs [14]. In the stratum corneum, the amorphous and highly refractive structures and the roundish aggregates of bright, small, polygonal/round cells seen under RCM (Figure 1A) correspond to hyperkeratotic scales and Munro microabscesses (Figure 1B), respectively. At the dermo-epidermal junction, the roundish dark areas with central canalicular structures containing bright elements $[14,15]$ seen under RCM (Figure 1C) correlate with the numerous, enlarged, dermal papillae containing dilated/tortuous capillary loops seen under HHS (Figure 1D). Moreover, these features are visible in the upper portion of the epidermis (just beneath the stratum corneum), as dermal papillae are superficialized due to the thinning of the suprapillary plate $[14,15]$.

Other RCM features correlating with HHSs are: the bright polygonal cells with dark center seen at the stratum corneum corresponding to parakeratosis; the honeycomb pattern appearing darker than the surrounding epidermis with widened intercellular spaces that corresponds to spongiosis; and small, polygonal/round, bright, hyper-reflecting cells interspersed among keratinocytes, reflecting inflammatory cell exocytosis [14]. 

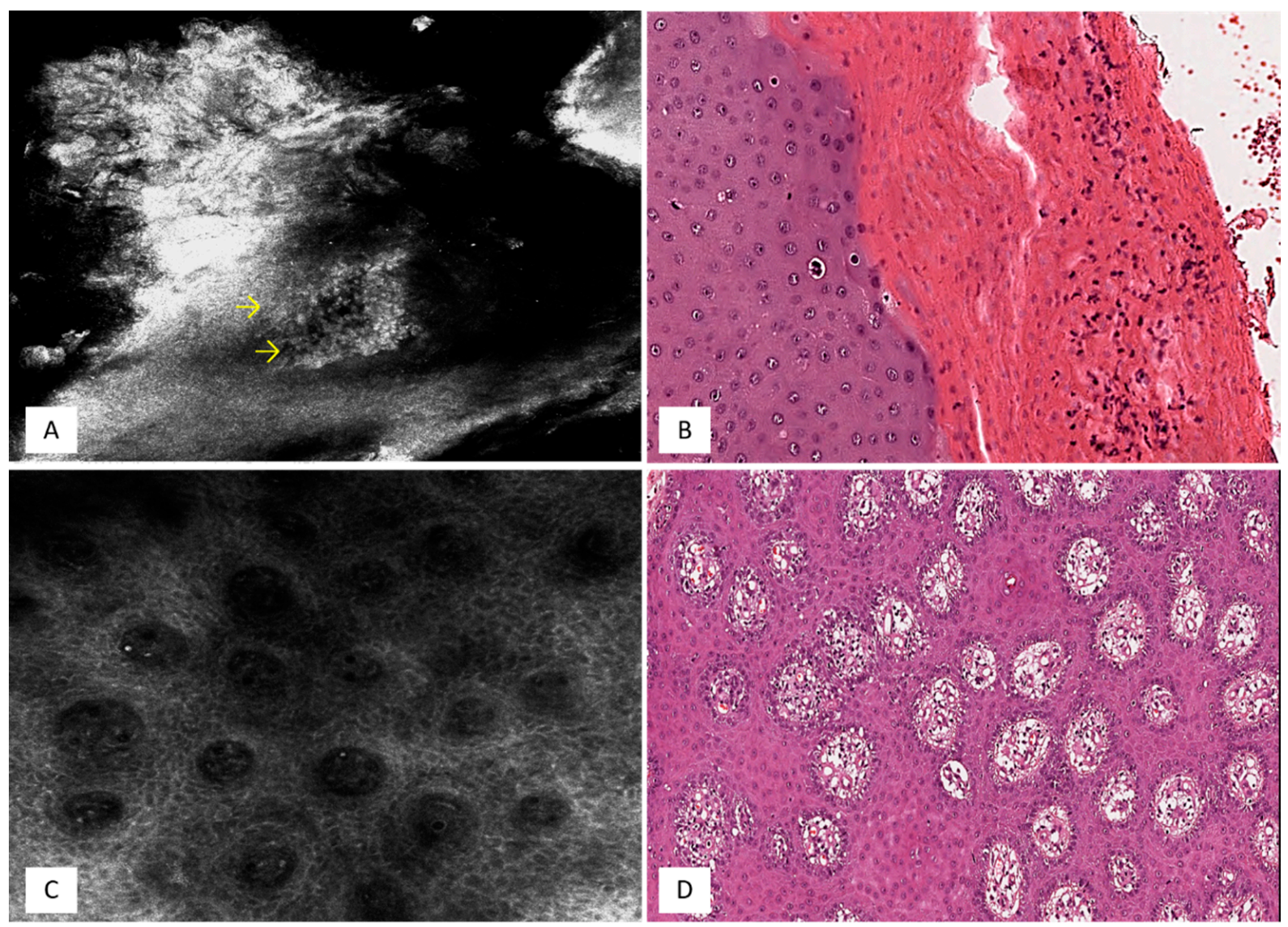

Figure 1. Stratum Corneum. (A) Under RCM, roundish aggregates of bright, small, polygonal/round cells (arrows) are seen. (B) Horizontal histopathology at the same level shows hyper-parakeratosis and infiltrating neutrophils (Munro microabscesses) (hematoxylin and eosin: original magnification $200 \times$ ). Dermo-epidermal Junction. (C) RCM showing homogeneously distributed, non-rimmed, enlarged dermal papillae filled with tortuous and dilated dark canalicular structures. (D) Superficialized and dilated dermal papillae filled with congested and tortuous capillary vessels are seen on HHSs (hematoxylin and eosin: original magnification $100 \times$ ).

\section{Discoid Lupus Erythematosus}

Discoid lupus erythematosus (DLE) is a chronic inflammatory disease that usually involves sun-exposed areas such as the face, upper trunk, and scalp [16]. Although any age group may be involved, it is most common in the third, fourth, and fifth decades, with a peak of incidence in the late thirties [17]. An established plaque of DLE is covered with an adherent scale accompanied by epidermal atrophy, follicular dilatation, and plugging $[18,19]$. These lesions heal with scarring, which is often marked.

The diagnosis of DLE may be improved by RCM that can detect the typical inflammatory infiltration in association with a vacuolar degeneration at the dermo-epidermal junction. RCM and HHS features have been compared, with a remarkable correspondence found at different depths [20]. In the stratum corneum, RCM reveals roundish areas filled with highly refractive material (Figure 2A) that in HHS correspond to dilated follicles with infundibular hyperkeratosis [20] (Figure 2B); at the dermo-epidermal junction, the epidermal disarrangement with the presence of several small polygonal/round bright cells seen using RCM (Figure 2C) correlates in HHS with vacuolar degeneration of the basal layer with inflammatory cell infiltration [20] (Figure 2D). 

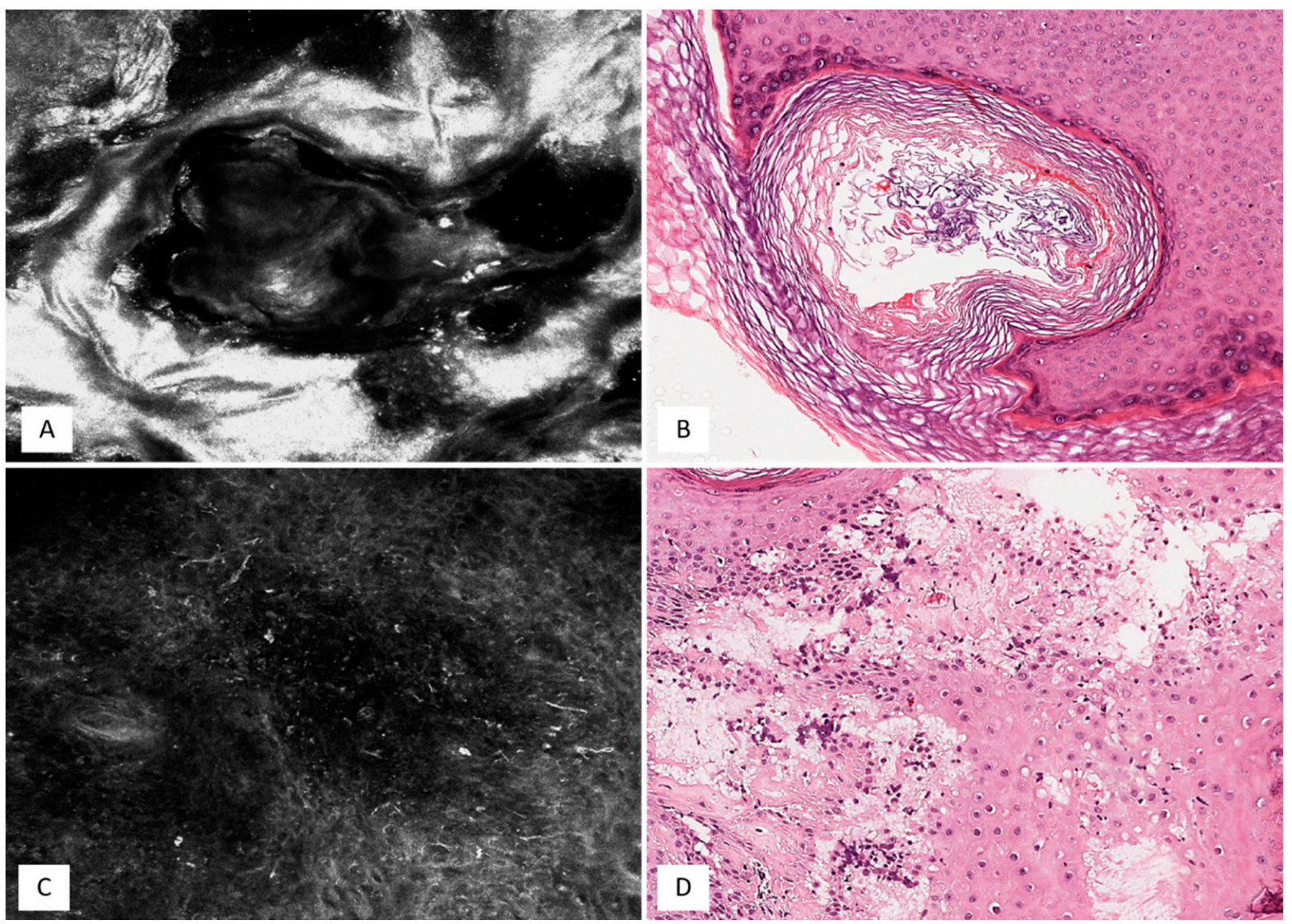

Figure 2. Stratum Corneum. (A) RCM shows roundish areas filled with highly refractive material. (B) HHSs exhibit dilated follicles with infundibular hyperkeratosis (follicular plugging) (hematoxylin and eosin: original magnification $200 \times$ ). Dermo-epidermal Junction. (C) Several small polygonal/round bright cells and some dendritic cells with partial disappearance of the dermal papillae are encountered on RCM. (D) Horizontal histopathology at the same level exhibits vacuolar degeneration of the basal layer with partial disappearance of dermal papillae and mild inflammatory infiltrate (hematoxylin and eosin: original magnification $100 \times$ ).

\section{Eczema}

Based on The Nomenclature Review Committee of The World Allergy Organization, eczema is the term by which atopic dermatitis is commonly referred to [21]; however, eczema includes both atopic and non-atopic forms [22]. The atopic subtype represents the most common form of eczema, and it is a chronic, recurrent cutaneous inflammatory disease, the clinical presentation of which ranges from itchy, erythematous papules and exudating vesicles in the acute/subacute stages to papules with areas of lichenification and excoriation in the chronic forms [22]. Atopic eczema (AE) is frequently associated with other atopic non-cutaneous manifestations, including asthma and allergic rhinitis [22]; it affects about $20-30 \%$ of children and $2-10 \%$ of adults [22]. The RCM features of eczema strongly overlap with those on horizontal histopathology [23]. In the stratum spinosum, RCM shows: (i) lesser refractive areas than those observed in the surrounding unaffected epidermis; (ii) expanded intercellular spaces; (iii) round-shaped, hyporefractive spaces; and (iv) scattered, roundish, mildly refractive inflammatory cells [23] (Figure 3A). On HHSs, these features match with spongiosis, the presence of vesicles, and lymphocytic exocytosis (Figure 3B), respectively [23]. In addition, the paucity of intraepidermal lymphocytes, commonly observed under RCM, allows clinicians to reliably distinguish eczema from mycosis fungoides patch lesions [23]. 

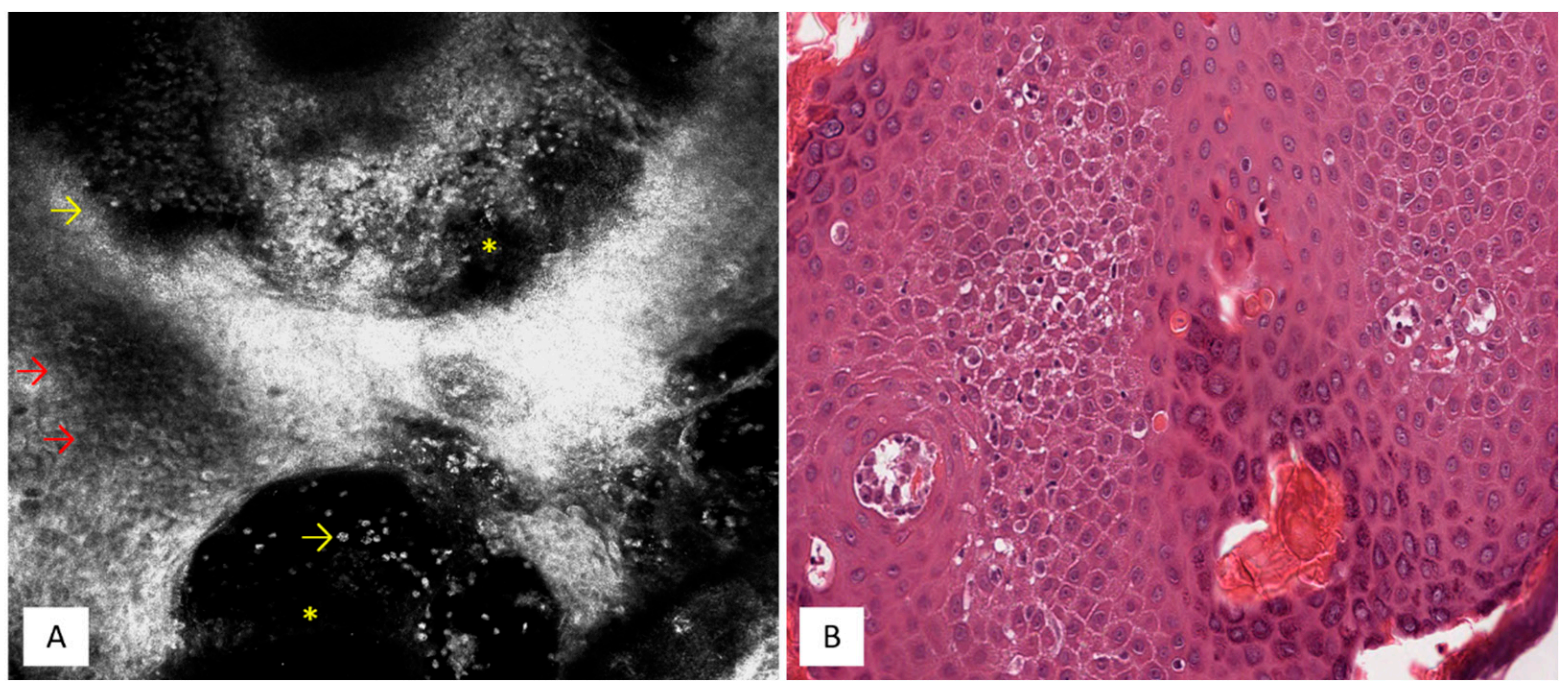

Figure 3. Stratum Spinosum. (A) Intraepidermal dark vesicular areas (asterisks) containing small mildly refractive cells (yellow arrows) and broadband intercellular spaces (red arrows) are seen under RCM. (B) RCM features correlate with spongiosis, vesicles, and mild lymphocytic exocytosis, seen on horizontal histopathology (hematoxylin and eosin: original magnification $200 \times$ ).

\section{Discussion}

Vertical histopathology represents the current "gold standard" approach to microscopically evaluate most biopsied and/or surgically excised skin samples, while HHSs are traditionally used for the diagnosis of some alopecia subtypes, as they allow pathologists to better visualize the follicular and perifollicular areas [1,24]. However, most of the commonly used diagnostic techniques in dermatology, including dermoscopy and RCM, take a horizontal point of view of the skin $[1,25,26]$ that differs from the vertical plane of conventional histopathology. Based on this, the use of HHSs has been described in the literature and proposed as a novel method to strongly validate the diagnostic accuracy of RCM and dermoscopy [1,14,20,23-26]. Importantly, the use of HHSs is aimed not to replace conventional histopathology but to further validate RCM features, highlighting cellular analogies between RCM and HHSs [1]. This strong correspondence has also been found in some skin tumors $[1,24,25]$, but, in our opinion, it can be particularly useful in the management of inflammatory diseases $[14,20,23,26]$. Some considerations have to be made: the demonstrated correlation between RCM features and HHSs in skin diseases reported in Table 1 may avoid the use of multiple biopsies for diagnostic confirmation, may allow a better selection of the sampling site, and, in selected cases, may solve differential diagnosis issues in case of diseases with similar clinical presentation.

In conclusion, although vertical histopathological sections still remain the best approach to obtain a certain diagnosis of most cutaneous disorders, the present review emphasizes the validity of RCM in the clinical evaluation of some inflammatory skin diseases, such as psoriasis, DLE, and eczematous dermatitis, as it provides clinicians with the same morphological features that can be seen via horizontal histopathology. In addition, the recent introduction of deep-learning-based frameworks able to transform in vivo RCM images into virtually stained hematoxylin-and-eosin-like images, if confirmed by large case series, might further expand the usefulness of RCM in inflammatory skin disorders [27].

In our experience, $\mathrm{RCM}$ represents a strong diagnostic aid that supports and improves the clinical and dermoscopic findings in both inflammatory and neoplastic skin diseases; it may also assume a decisive diagnostic role for diseases with overlapping clinical and dermoscopic features. 
Table 1. Summary of the correlation between RCM and HHS results in inflammatory skin diseases.

\begin{tabular}{|c|c|c|c|}
\hline & Skin Level & $\mathrm{RCM}$ & HHSs \\
\hline $\begin{array}{c}\text { Psoriasis } \\
{[8]}\end{array}$ & $\begin{array}{l}\text {-S corneum } \\
\text {-S granulosum/spinosum } \\
\text {-DEJ }\end{array}$ & $\begin{array}{l}\text {-Bright structures with detached keratinocytes } \\
\text {-Hyperrefractile nuclei surrounded by } \\
\text { dark cytoplasm } \\
\text {-Dark, roundish areas containing bright particles } \\
\text {-Islands of keratinocytes with broadened white or } \\
\text { grayish outlines } \\
\text {-Dark circles within the dermal papillae }\end{array}$ & $\begin{array}{c}\text {-Hyperkeratosis } \\
\text {-Parakeratosis } \\
\text {-Munro microabscesses } \\
\text {-Acanthosis } \\
\text {-Papillomatosis }\end{array}$ \\
\hline DLE [14] & $\begin{array}{l}\text { S corneum } \\
\text { DEJ }\end{array}$ & $\begin{array}{l}\text {-Roundish areas filled with highly refractive material } \\
\text {-Disarrangement } \\
\text {-Small polygonal/round bright cells }\end{array}$ & $\begin{array}{l}\text {-Dilated follicles with } \\
\text { infundibular } \\
\text { hyperkeratosis } \\
\text {-Vacuolar degeneration } \\
\text {-Inflammatory infiltrate }\end{array}$ \\
\hline $\begin{array}{c}\text { Eczema } \\
{[17]}\end{array}$ & S granulosum/spinosum & $\begin{array}{c}\text {-Expanded intercellular spaces } \\
\text {-Round-shaped hyporefractive spaces } \\
\text {-Scattered roundish, mildly refractive cells }\end{array}$ & $\begin{array}{c}\text {-Spongiosis } \\
\text {-Vesicles } \\
\text {-Lymphocytic exocytosis }\end{array}$ \\
\hline
\end{tabular}

Abbreviations: RCM, reflectance confocal microscopy; HHSs, horizontal histopathological sections; S, stratum; DEJ, dermo-epidermal junction; DLE, discoid lupus erythematosus.

Author Contributions: Conceptualization, G.B. and R.C.; investigation, A.E.V., F.L. and G.M.; writing-original draft preparation, G.B.; writing-review and editing, G.B., G.M. and R.C. All authors have read and agreed to the published version of the manuscript.

Funding: This research received no external funding.

Institutional Review Board Statement: Not applicable.

Informed Consent Statement: Not applicable.

Data Availability Statement: All data presented in this manuscript are available from the corresponding author upon reasonable request.

Conflicts of Interest: The authors declare no conflict of interest.

\section{References}

1. Broggi, G.; Verzì, A.E.; Caltabiano, R.; Micali, G.; Lacarrubba, F. Correlation between in vivo Reflectance Confocal Microscopy and Horizontal Histopathology in skin cancer: A review. Front. Oncol. 2021, 11, 653140. [CrossRef] [PubMed]

2. Ilie, M.A.; Caruntu, C.; Lixandru, D.; Tampa, M.; Georgescu, S.R.; Constantin, M.M.; Constantin, C.; Neagu, M.; Zurac, S.A.; Boda, D. In vivo confocal laser scanning microscopy imaging of skin inflammation: Clinical applications and research directions. Exp. Ther. Med. 2019, 17, 1004-1011. [CrossRef] [PubMed]

3. Shahriari, N.; Rabinovitz, H.; Oliviero, M.; Grant-Kels, J.M. Reflectance confocal microscopy: Melanocytic and nonmelanocytic. Clin. Dermatol. 2021, 39, 643-656. [CrossRef] [PubMed]

4. Ko, R.F.; Smidt, A.C.; Durkin, J.R. Reflectance confocal microscopy in pediatric dermatology: A state-of-the-art review. Pediatr. Dermatol. 2021, 38, 1488-1499. [CrossRef] [PubMed]

5. Du, X.; Li, Z.; Xu, W.; Zhou, X.; Tang, S.; Song, C.; Fan, W. Diagnostic value of horizontal versus vertical sections for scarring and non-scarring alopecia: A systematic review and meta-analysis. Eur. J. Dermatol. 2016, 26, 361-369. [CrossRef]

6. Olsen, E.A.; Bergfeld, W.F.; Cotsarelis, G.; Price, V.H.; Shapiro, J.; Sinclair, R.; Solomon, A.; Sperling, L.; Stenn, K.; Whiting, D.A.; et al. Summary of North American Hair Research Society (NAHRS)-sponsored Workshop on Cicatricial Alopecia, Duke University Medical Center, February 10 and 11, 2001. J. Am. Acad. Dermatol. 2003, 48, 103-110. [CrossRef] [PubMed]

7. Palo, S.; Biligi, D.S. Utility of horizontal and vertical sections of scalp biopsies in various forms of primary alopecias. J. Lab. Physicians 2018, 10, 95-100. [CrossRef]

8. Greb, J.E.; Goldminz, A.M.; Elder, J.T.; Lebwohl, M.G.; Gladman, D.D.; Wu, J.J.; Mehta, N.N.; Finlay, A.Y.; Gottlieb, A.B. Psoriasis. Nat. Rev. Dis. Prim. 2016, 2, 16082. [CrossRef]

9. Langley, R.G.; Krueger, G.G.; Griffiths, C.E. Psoriasis: Epidemiology, clinical features, and quality of life. Ann. Rheum. Dis. 2005, 64 (Suppl. 2), ii18-ii23. [CrossRef] [PubMed]

10. Griffiths, C.E.; Barker, J.N. Pathogenesis and clinical features of psoriasis. Lancet 2007, 370, 263-271. [CrossRef]

11. Boehncke, W.H.; Schön, M.P. Psoriasis. Lancet 2015, 386, 983-994. [CrossRef]

12. Lacarrubba, F.; Pellacani, G.; Gurgone, S.; Verzì, A.E.; Micali, G. Advances in non-invasive techniques as aids to the diagnosis and monitoring of therapeutic response in plaque psoriasis: A review. Int. J. Dermatol. 2015, 54, 626-634. [CrossRef] 
13. Lacarrubba, F.; Musumeci, M.L.; Ferraro, S.; Stinco, G.; Verzì, A.E.; Micali, G. A three-cohort comparison with videodermatoscopic evidence of the distinct homogeneous bushy capillary microvascular pattern in psoriasis vs atopic dermatitis and contact dermatitis. J. Eur. Acad. Dermatol. Venereol. 2016, 30, 701-703. [CrossRef]

14. Verzì, A.E.; Lacarrubba, F.; Caltabiano, R.; Broggi, G.; Musumeci, M.L.; Micali, G. Reflectance Confocal Microscopy Features of Plaque Psoriasis Overlap With Horizontal Histopathological Sections: A Case Series. Am. J. Dermatopathol. 2019, $41,355-357$. [CrossRef]

15. Nasca, M.R.; Lacarrubba, F.; Caltabiano, R.; Micali, G. Image Gallery: Reproduction of the Auspitz sign by videodermatoscopy, confocal microscopy and horizontal histopathology. Br. J. Dermatol. 2019, 180, e178. [CrossRef]

16. Walling, H.W.; Sontheimer, R.D. Cutaneous lupus erythematosus: Issues in diagnosis and treatment. Am. J. Clin. Dermatol. 2009, 10, 365-381. [CrossRef]

17. Michel, M.; Johanet, C.; Meyer, O.; Francès, C.; Wittke, F.; Michel, C.; Arfi, S.; Tournier-Lasserve, E.; Piette, J.C.; Group for Research on Auto-Immune Disorders (GRAID). Familial lupus erythematosus. Clinical and immunologic features of 125 multiplex families. Medicine 2001, 80, 153-158. [CrossRef] [PubMed]

18. Żychowska, M.; Żychowska, M. Dermoscopy of discoid lupus erythematosus-a systematic review of the literature. Int. J. Dermatol. 2021, 60, 818-828. [CrossRef] [PubMed]

19. Donnelly, A.M.; Halbert, A.R.; Rohr, J.B. Discoid lupus erythematosus. Australas. J. Dermatol. 1995, 36, 3-10, quiz 11-2. [CrossRef] [PubMed]

20. Lacarrubba, F.; Verzì, A.E.; Caltabiano, R.; Broggi, G.; Di Natale, A.; Micali, G. Discoid lupus erythematosus: Reflectance confocal microscopy features correlate with horizontal histopathological sections. Ski. Res. Technol. 2019, 25, 242-244. [CrossRef] [PubMed]

21. Rożalski, M.; Rudnicka, L.; Samochocki, Z. Atopic and Non-atopic Eczema. Acta Dermatovenerol. Croat. 2016, $24,110-115$. [PubMed]

22. Sohn, A.; Frankel, A.; Patel, R.V.; Goldenberg, G. Eczema. Mt. Sinai J. Med. 2011, 78, 730-739. [CrossRef] [PubMed]

23. Broggi, G.; Lacarrubba, F.; Verzì, A.E.; Micali, G.; Caltabiano, R. Confocal microscopy features of patch-stage mycosis fungoides and their correlation with horizontal histopathological sections. A case series. J. Cutan. Pathol. 2019, 46, 163-165. [CrossRef] [PubMed]

24. Broggi, G.; Verzì, A.E.; Lacarrubba, F.; Caltabiano, R.; Di Natale, A.; Micali, G. Correlation between reflectance confocal microscopy features and horizontal histopathology in cutaneous squamous cell carcinoma in situ: A case series. J. Cutan. Pathol. 2020, 47, 777-780. [CrossRef]

25. Xiong, Y.Q.; Ma, S.J.; Mo, Y.; Huo, S.T.; Wen, Y.Q.; Chen, Q. Comparison of dermoscopy and reflectance confocal microscopy for the diagnosis of malignant skin tumours: A meta-analysis. J. Cancer Res. Clin. Oncol. 2017, 143, 1627-1635. [CrossRef]

26. Mazzilli, S.; Vollono, L.; Diluvio, L.; Botti, E.; Costanza, G.; Campione, E.; Donati, M.; Prete, M.D.; Orlandi, A.; Bianchi, L.; et al. The combined role of clinical, reflectance confocal microscopy and dermoscopy applied to chronic discoid cutaneous lupus and subacutus lupus erythematosus: A case series and literature review. Lupus 2021, 30, 125-133. [CrossRef]

27. Li, J.; Garfinkel, J.; Zhang, X.; Wu, D.; Zhang, Y.; de Haan, K.; Wang, H.; Liu, T.; Bai, B.; Rivenson, Y.; et al. Biopsy-free in vivo virtual histology of skin using deep learning. Light Sci. Appl. 2021, 10, 233. [CrossRef] [PubMed] 